\title{
Effect of Stove Technology and Combustion Conditions on Gas and Particulate Emissions from Residential Biomass Combustion
}

Deepika Bhattu, ${ }^{*}{ }^{\dagger}$ Peter Zotter, ${ }^{\dagger \odot}$ Jun Zhou, ${ }^{\dagger, \|}$ Giulia Stefenelli, ${ }^{\dagger}$ Felix Klein, ${ }^{\dagger}$ Amelie Bertrand, ${ }^{\dagger, \S}$ Brice Temime-Roussel, ${ }^{\S}$ Nicolas Marchand, ${ }^{\S}$ Jay G. Slowik, ${ }^{\dagger}$ Urs Baltensperger, ${ }^{\dagger}$ André Stephan Henry Prévôt, ${ }^{\dagger}{ }^{\dagger}$ Thomas Nussbaumer, ${ }^{\ddagger}$ Imad El Haddad, ${ }^{\dagger}$ and Josef Dommen*, ${ }^{\dagger}$

${ }^{\dagger}$ Laboratory of Atmospheric Chemistry, Paul Scherrer Institute, 5232 Villigen, Switzerland

${ }^{\ddagger}$ Bioenergy Research, Engineering and Architecture, Lucerne University of Applied Sciences and Arts, 6048 Horw, Switzerland

${ }^{\S}$ Aix Marseille Univ, CNRS, LCE, Marseille, France

\author{
Supporting Information
}

ABSTRACT: We have systematically examined the gas and particle phase emissions from seven wood combustion devices. Among total carbon mass emitted (excluding $\mathrm{CO}_{2}$ ), $\mathrm{CO}$ emissions were dominant, together with nonmethane volatile organic compounds (NMVOCs) (10-40\%). Automated devices emitted $1-3$ orders of magnitude lower $\mathrm{CH}_{4}$ (0.002-0.60 $\mathrm{g} \mathrm{kg}^{-1}$ of wood) and NMVOCs (0.01-1 $\mathrm{g} \mathrm{kg}^{-1}$ of wood) compared to batch-operated devices $\left(\mathrm{CH}_{4}: 0.25-\right.$ $2.80 \mathrm{~g} \mathrm{~kg}^{-1}$ of wood; NMVOCs: $2.5-19 \mathrm{~g} \mathrm{~kg}^{-1}$ of wood). $60-90 \%$ of the total NMVOCs were emitted in the starting phase of batch-operated devices, except for the first load

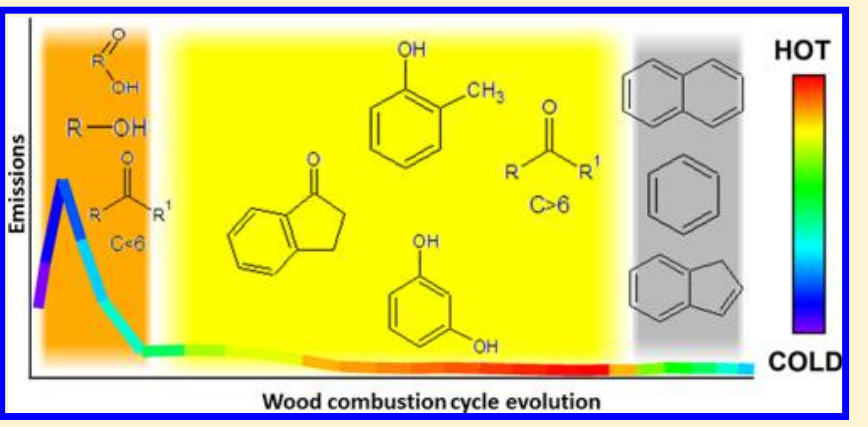
cycles. Partial-load conditions or deviations from the normal recommended operating conditions, such as use of wet wood/wheat pellets, oxygen rich or deficit conditions, significantly enhanced the emissions. NMVOCs were largely dominated by small carboxylic acids and alcohols, and furans. Despite the large variability in NMVOCs emission strengths, the relative contribution of different classes showed large similarities among different devices and combustion phases. We show that specific improper operating conditions may even for advanced technology not result in the emission reduction of secondary organic aerosol (SOA) forming compounds and thus not reduce the impact of wood combustion on climate and health.

\section{INTRODUCTION}

Increasing world energy demands (by 28\% between 2015 and $2040)^{1}$ and identification of climatic effects from fossil fuel combustion accentuate the need for alternative energy sources. While wood is a potent renewable heat and energy source, it is also a significant source of primary particulate matter (PM) and secondary PM precursors, linked to adverse human health effects. The incomplete combustion products (ICPs) present in biomass smoke such as $\mathrm{CO}, \mathrm{CH}_{4}$, nonmethane volatile organic compounds (NMVOCs), black carbon (BC), and organic aerosols (OA) deteriorate air quality. ${ }^{2-6}$ Studies showed the occurrence of DNA damage, lipid peroxidation and release of pro-inflammatory cytokines in lung cells can be caused by wood combustion emissions. ${ }^{7-11}$

After biogenic emissions, ${ }^{12}$ biomass burning is the second largest global contributor to atmospheric NMVOCs. ${ }^{13}$ Among the latter, a significant portion may be comprised of unidentified high molecular weight species, ${ }^{14-16}$ which are associated with the rapid formation of secondary organic aerosol (SOA), ${ }^{4,17-20}$ secondary NMVOCs and ground level ozone $\left(\mathrm{O}_{3}\right)^{21-25}$ Extensive laboratory studies have focused on open biomass burning under fuel rich conditions for specific fuels, ${ }^{14,16,24,26-36}$ but few studies are available on NMVOC emissions from residential wood combustion. ${ }^{37-49}$ Among them, most of the studies deployed offline sampling techniques such as Tedlar bags or PUF/Tenax-TA/DNPH-Silica/ $\mathrm{C}_{18}$ Sep Pak cartridges or stainless steel canisters either for a complete combustion cycle or separately for different combustion phases and/or averaged over several batches. Such measurements are time-consuming and limited to a small range of compounds, for example, small carbonyls, sugars, polycyclic aromatic hydrocarbons, single ring aromatics $^{38,40,41,47}$ in comparison to online instrumentation. $^{43,45}$ In addition, a great majority has investigated photochemically aged emissions ${ }^{17,42,45,46,50-55}$ but very few examined the real-time influence of combustion conditions and technology on the emitted NMVOCs composition. ${ }^{56,57}$

Due to economic considerations and wood availability, residential wood heating is likely to persist in many parts of the world in the near future. Moreover, large incentives/

Received: September 6, 2018

Revised: January 14, 2019

Accepted: January 16, 2019

Published: January 16, 2019 
subsidies to induce a shift from fossil to renewable energy production and the introduction of more stringent emission legislations ${ }^{58}$ have led to developments of combustion technology with varying configurations: from process control perspective, level of sophistication, and performance. ${ }^{59}$ The variations in the present investigation range from simple, low cost, manually operated technologies, that is, conventional single-stage combustion logwood stoves, to well-regulated, automated devices. In the past, the combustion quality and claimed reduced emissions are often compared focusing on commonly measured gas phase emissions ( $\mathrm{CO}$, total VOCs, and $\mathrm{NO}_{X}$ ) and total particle emissions and investigating only part of the combustion cycle. However, further information on the flue gas chemical composition is needed to evaluate the environmental impacts resulting from a shift toward more advanced technologies.

The present study compares real-time emissions from different combustion technologies. First, we examine the interand intraburn variability of conventional emissions $\left(\mathrm{CO}, \mathrm{CH}_{4}\right.$, $\mathrm{NO}, \mathrm{eBC}$ ), POA and total NMVOCs among different tested devices to understand the effect of fuel and combustion parameters such as temperature, MCE and $\lambda$ (see Section 3.1). Second, we evaluate the effect of stove technology on the evolution of emissions during the combustion cycle. We compare these emissions with those from automated devices tested in this study and literature values (see section 3.2). Third, we analyze the evolution of different classes of NMVOCs emission along the combustion cycle for different technologies in order to evaluate the performance of conventional and advanced technologies (Section 3.3). Fourth, we explored the dependence of individual NMVOC emission intensity, variability and chemical composition on combustion conditions including device and load type (first load/reloads), and combustion phases (Section 3.4).

\section{MATERIALS AND METHODS}

2.1. Tested Devices and Their Operating Conditions. Primary gas and particle phase emissions across six residential wood combustion devices (94 test burns) and one industrial boiler (six test runs) were characterized in real-time. We present the full suite of the current technology used in Swiss households with different fuel types and properties. The tested devices include the following (specified with manufacturing year and rated power): (a) two-stage combustion pellet operated devices: pellet boiler (device 1, 2004, $15 \mathrm{~kW}$ ) and pellet stove (device 4, 2010, 2-6 kW), (b) two-stage combustion logwood operated devices: logwood boiler (device 2, 2007, $30 \mathrm{~kW}$ ), advanced twostage combustion logwood stoves (device 6, 2013, $4.6 \mathrm{~kW}$ and device 7, 2016, $8 \mathrm{~kW})$, (c) conventional single-stage combustion logwood stove (device 5, 2005, $6 \mathrm{~kW}$ ), and (d) industrial wood chip moving grate boiler (device 3, 2013, $150 \mathrm{~kW}$ ). Device 1, 3, and 5 were tested in 2015 and 2, 4, 6, and 7 in 2016. Fuels tested included wood pellets (EN certified, a quality standard developed by European Committee for Standardization) and wheat pellets, wood chips and logs made of beech wood with additional small pieces of soft wood (300-600 g) and fire kindling $(20-30 \mathrm{~g})$ as starters only during first loads. Supporting Information (SI) Table S1 presents the properties of fuels used in this study. Effect of different fuel properties was tested with fuel of different moisture contents (dry $(\sim 13-16 \%)$ and wet $(\sim 20-42 \%))$ and fuel load conditions (normal and overload). Apart from their recommended combustion regimes, device 1 was also investigated during excess $\left(\lambda_{++}\right)$and lack $\left(\lambda_{--}\right)$of $\mathrm{O}_{2}$ conditions, and devices 3 and 4 were tested under partial-load. Logwood operated devices $(2,5,6$, and 7$)$ were investigated for the complete combustion cycles with the first cycle referred to as "first load" and subsequent cycles, as "reloads". The first load consisted of a cold start, flaming and burn-out phase, and reloads were comprised of a warm start, flaming and burn-out phase. More details on the specifications, operating conditions and combustion regimes of the tested devices are provided in the SI (Table S2 and Section S1).

2.2. Sampling Details. Details of the experimental setup and sampling strategy along with the operated instrumentation are given in SI Figure S1 and Section S2. Briefly, undiluted flue gas was measured through a thermally insulated heated line at $180^{\circ} \mathrm{C}$ using a multigas analyzer system (Ultramat 23 Siemens; $\mathrm{CO}$ and NO: nondispersive infrared (NDIR) and $\mathrm{O}_{2}$ : paramagnetic measurement) and a flame ionization detector (FID) with nonmethane cutter (109A, J.U.M Engineering: VOC and $\left.\mathrm{CH}_{4}\right)$. Only $\mathrm{CH}_{4}$ concentrations were used from FID. Further downstream, emissions were sampled after passing through two serially connected heated ejector dilutors (first at $180^{\circ} \mathrm{C}$ and second at $100{ }^{\circ} \mathrm{C}$ ), each with a dilution ratio of $1: 10$ (DI-1000, Dekati Ltd.).

2.3. Instrumentation. NMVOCs were measured by a proton transfer reaction time-of-flight mass spectrometer (PTRTOF-MS 8000, Ionicon Analytik G.m.b.H) operated with 6 and 10 s time resolution in 2015 and 2016, respectively. Sampled NMVOCs were protonated with $\mathrm{H}_{3} \mathrm{O}^{+}$ions in the drift tube maintained at a drift voltage of $494 \mathrm{~V}$, temperature of 90-100 ${ }^{\circ} \mathrm{C}$, and pressure of 2.19-2.2 mbar resulting in $\mathrm{E} / \mathrm{N}=125-129$ Td. For a quantitative determination ${ }^{60}$ of the VOC concentration ( $\mathrm{ppb}$ ), the mass resolution, mass accuracy and relative transmission function were determined by calibrating with common VOCs $(m / z 33$ to 181 ; Carbagas AG, Zurich, Switzerland) of known abundances (SI Figure S2 and Section S2.2). Data were analyzed with Tofware postprocessing software (version 2.5.3, TOFWERK AG, Thun, Switzerland). Reaction rate constants of the NMVOCs with $\mathrm{H}_{3} \mathrm{O}^{+}$were used from the literature ${ }^{61}$ when available, otherwise a default rate constant of 2 $\times 10^{-9} \mathrm{~cm}^{3}$ molecule $\mathrm{s}^{-1}$ was used. The high resolution of the PTR-TOF-MS allowed the molecular formula assignments. Tentative peak identification was based on literature reports on wood combustion emissions from both laboratory and field experiments (SI Table S3). ${ }^{31,37,42,43,62}$ Identified ions were classified according to their functional groups into 14 classes, including furans, hydrocarbons (HC), N-containing compounds ( $\mathrm{N}$ is nitrogen atoms), polycyclic aromatic hydrocarbons (PAHs), single-ring aromatics (SRA), O-containing_acids ( $\mathrm{O}$ is oxygen atoms), O-containing alcohols, O-containing_C $<6$ (where $\mathrm{C}$ is the number of carbon atoms), $\mathrm{O}$ containing_C $>6$, oxygenated aromatics_benzenediols/methoxy-phenols, oxygenated aromatics methylphenols, oxygenated aromatics oxygenated PAHs, and oxygenated aromatics others, whereas the unidentified ions were congregated under "Others".

An aethalometer (AE 33, Magee Scientific) was used to determine the aerosol attenuation coefficients at seven wavelengths, from which the equivalent $\mathrm{BC}(\mathrm{eBC})$ mass concentration was retrieved. ${ }^{63}$ Primary organic aerosol (POA) mass concentration was obtained using an Aerodyne high resolution time-of-flight aerosol mass spectrometer (HR-TOF-AMS, Aerodyne Research Inc.). Details on additional measurements can be found elsewhere. ${ }^{36}$ 


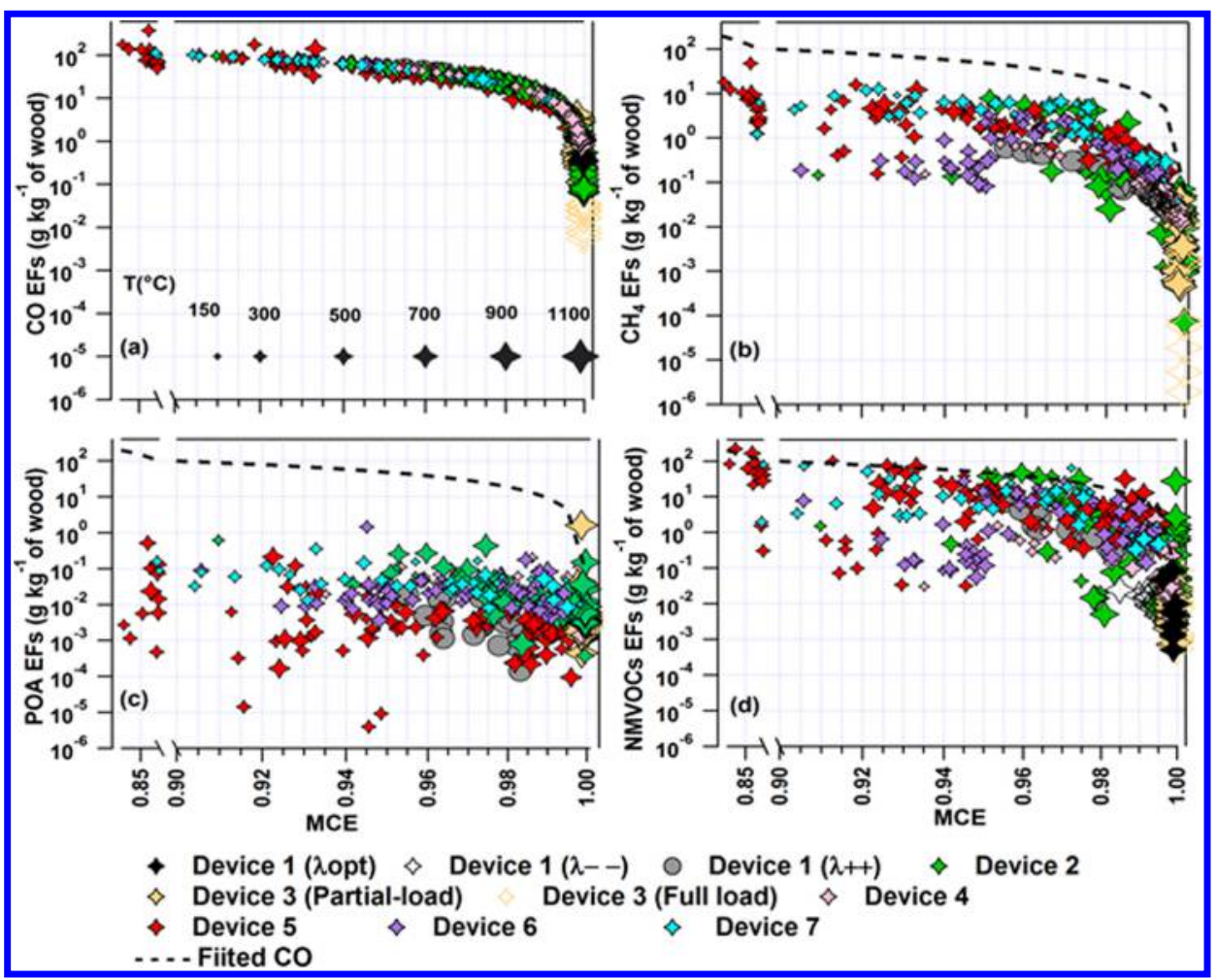

Figure 1. Combustion phase-specific gas phase (a: $\mathrm{CO}, \mathrm{b}: \mathrm{CH}_{4}, \mathrm{c}: \mathrm{POA}$ and d: NMVOCs) $\mathrm{EFs}\left(\mathrm{g} \mathrm{kg}^{-1}\right.$ of wood) vs MCE for seven combustion devices and their operating conditions (partial-/full load and excess $\left(\lambda_{++}\right)$, lack $\left(\lambda_{--}\right)$, and optimum $\lambda\left(\lambda_{\text {opt }}\right)$ condition) represented by different colored markers. Marker size refers to the combustion chamber temperature ranging from 150 to $1150{ }^{\circ} \mathrm{C}$. The dashed black line in panel b-d is the fitted CO EF from panel a. The particle phase measurements in device 3 (moving grate boiler) refer to measurements before the electrostatic precipitator.

2.4. Data Analysis. Primary emission factors (EFs, $\mathrm{mg} \mathrm{kg}^{-1}$ of wood given in SI Table S3) of conventional gases $\left(\mathrm{CO}_{2}, \mathrm{CO}\right.$, and $\mathrm{CH}_{4}$ ), NMVOCs (PTR-MS) and particle phase species were calculated, following a carbon-mass-balance approach ${ }^{64}$ as described in eq 1 .

$$
\mathrm{EF}_{x}=\frac{\Delta x}{\Delta\left[C_{\mathrm{CO}_{2}}\right]+\Delta\left[C_{\mathrm{CO}}\right]+\Delta\left[C_{\mathrm{CH}_{4}}\right]+\Delta\left[C_{\mathrm{VOC}}\right]+\Delta\left[C_{\mathrm{OC}}\right]+\Delta\left[C_{\mathrm{eBC}}\right]} \times f_{\mathrm{c}}
$$

Here, $\Delta x$ is the background-corrected concentration of the species of interest, and $\Delta\left[C_{\mathrm{CO}_{2}}\right], \Delta\left[C_{\mathrm{CO}}\right], \Delta\left[C_{\mathrm{CH}_{4}}\right], \Delta\left[C_{\mathrm{VOC}}\right]$, $\Delta\left[C_{\mathrm{OC}}\right]$, and $\Delta\left[C_{\mathrm{eBC}}\right]$ are the background-corrected carbon mass concentrations of carbon containing species in the flue gas. For the carbon fraction $f_{c}$ in the fuel a constant average value of the wood (0.46; SI Table S1) was assumed. Changes of $f_{\mathrm{c}}$ over the burning cycle are expected to be small compared to the variability of the pollutant emissions and difficult to determine for all devices. OC is derived by dividing OM by the OM:OC ratio obtained from the AMS measurements. For automatic device 4 and devices with full combustion cycles $(2,5,6$, and 7$)$, modified combustion efficiency $\left(\mathrm{MCE}=\left[\mathrm{CO}_{2} /\left(\mathrm{CO}_{2}+\right.\right.\right.$ $\mathrm{CO})])^{65}$ is used to determine the combustion phases (start $\approx$ $<0.974$, flaming and full/partial-load $>0.974$ and burn-out $<0.974 .{ }^{36}$ Accordingly, the combustion phase-specific "averaged EFs" are separately calculated from the EFs of several test cycles of the start, flaming and burn-out phases. These "averaged EFs" of the species mentioned above along with the combustion conditions, MCE and air fuel equivalence ratio, are provided in SI Table S3. The air fuel equivalence ratio is represented as $\lambda$ $\left[21[\%] /\left(21[\%]-\mathrm{O}_{2}[\%]\right)\right]$ where $21[\%]$ and $\mathrm{O}_{2}[\%]$ are the ambient and flue gas $\mathrm{O}_{2}$ content, respectively. ${ }^{66}$
The cumulative emission factors $\left(X_{i}\right)$ were examined only across batch-operated devices during different combustion cycles (see Sections 3.2 and 3.3). Here, $X_{i}\left(\mathrm{~g} \mathrm{~kg}^{-1}\right.$ of wood) is defined as the integrated emissions of the species $i$ during a time period $t$ over the total mass of wood burned:

$$
X_{i}=\left(\frac{\int_{0}^{t} C_{i} \times Q \mathrm{~d} t}{\left(\int_{o}^{\infty} \mathrm{CO}_{2} \times Q \mathrm{~d} t\right) \times\left(\frac{M_{\mathrm{C}}}{M_{\mathrm{CO}_{2}}}\right)}\right) \times f_{\mathrm{c}}
$$

Here $C_{i}$ and $\mathrm{CO}_{2}$ are the background-corrected mass concentrations $\left(\mathrm{g} \mathrm{m}^{-3}\right)$ of species $i$ and $\mathrm{CO}_{2}$, respectively. $Q$ is the flue gas flow rate $\left(\mathrm{m}^{3} \mathrm{hr}^{-1}\right)$, and $M_{\mathrm{C}}$ and $M_{\mathrm{CO}_{2}}$ are the molecular weights of carbon and $\mathrm{CO}_{2}$, respectively. $\mathrm{CO}_{2}$ is selected to serve as a tracer for fuel consumed as it comprises the major fraction $(>95 \%)$ of the total emissions.

Finally, we applied an unsupervised agglomerative twodimensional hierarchical clustering analysis (2D-HCA ${ }^{37,67-69}$ ) to the EFs of identified NMVOCs during different combustion phases to identify the main sources driving the chemical variation in the gas-phase. We have only considered devices 1,2 , 5,6 , and 7; devices 3 and 4 were excluded due to their extremely low EFs. More details on data preparation, clustering process, 


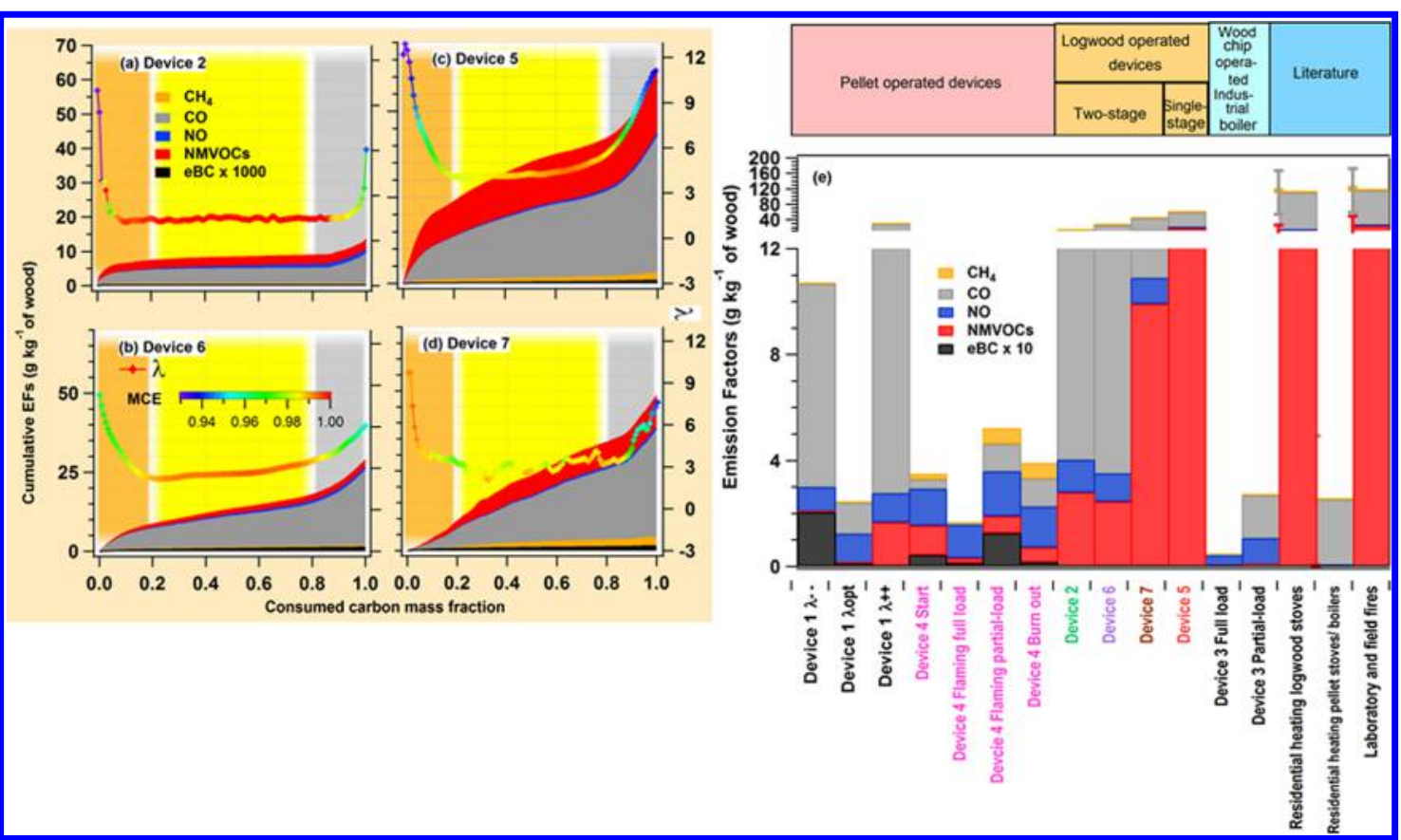

Figure 2. (a-d) Cumulative EFs of $\mathrm{CO}, \mathrm{CH}_{4}$, NO, NMVOCs, and eBC in $\mathrm{g} \mathrm{kg}^{-1}$ of wood emitted per consumed carbon mass fraction (calculated using eq 2) for logwood batch-operated devices $(2(n=1), 5(n=9), 6(n=7)$, and $7(n=5))$ and corresponding $\lambda$ values (right axis) color coded with MCE. The orange, yellow, and gray shaded areas represent start, flaming and burn-out phase, respectively. For device 2 and 7 , cumulative EFs represent first load and for device 5 and 6, average of both first load and reload combustion cycles. (e) Combustion phase-specific EFs of the above-mentioned species (stacked) from two-stage combustion pellet boiler and pellet stove, and wood chip operated industrial boiler (data available in SI Table S3) and cumulative EFs of the same species from the complete cycle of batch logwood operated devices (similar to the end points from panels a-d). As each set of experiment has one first load and several reloads (4-6), the effect of first loads in averaged cumulative EFs is not dominant in device 5 and 6 . The particle phase measurements in device 3 (moving grate boiler) refer to measurements before the electrostatic precipitator. Averaged EFs for CO, NMVOCs, and $\mathrm{CH}_{4}$ for residential heating and laboratory field fires from literature are also compared. Specific $\mathrm{EFs} \mathrm{for} \mathrm{CO}, \mathrm{CH}_{4}, \mathrm{NMVOCs}^{41}$ or NMHCs (nonmethane hydrocarbons), ${ }^{45} \mathrm{POA}$ or OC (organic carbon) and eBC from individual studies are provided in SI Figure S7.

statistical analysis and cluster validation are given in SI Section S3.

\section{RESULTS AND DISCUSSION}

3.1. Emissions of Gas and Particle Phase Species. The EFs of $\mathrm{CO}, \mathrm{CH}_{4}$, NMVOCs, POA, and $\mathrm{eBC}$ varied within $\sim 5$ orders of magnitude depending on the combustion device, combustion phase and fuel type used. Figure $1(a-d)$ shows this variability as a function of the governing combustion parameters, that is, MCE and combustion chamber temperature. SI Figure S4 shows the same data against $\lambda$. The optimum $\lambda$, where the lowest $\mathrm{CO}$ emission occurred, varied significantly between devices (device 1: 1.6; device 2: 1.5; device 3: 2.0; device 4: 3.9; device 5: 4.6; device 6: 2.5; device 7: 2.5) (SI Figure S4). This indicates that $\lambda$ does not only depend on the combustion conditions, but also on the device design (e.g., fuel feeding or airstaging system, combustion temperature and residence time of flue gas in the postcombustion chamber). The emissions of the gaseous species increased at lower and higher $\lambda$ values, representative of nonideal combustion conditions. Similarly, combustion temperature depends strongly on the measurement location, which varied with different combustion chamber designs and the technical possibility of the insertion of a temperature probe. Consequently, decreasing EFs with increasing combustion chamber temperature in Figure 1 and SI Figure S4 are limited to intradevice comparison only. Comparing all devices, $\mathrm{CO}$ EFs were $\sim 10$ times higher than those of $\mathrm{CH}_{4}$ at lower MCE $(<0.95)$ and their difference decreased strongly for MCE $>0.95$. CO emissions (Figure 1a) in automated (device 1, 3 and 4) devices were $\sim 10$ times higher than for NMVOCs (Figure 1d). But due to the large variability in NMVOCs EFs ( 1 order of magnitude) of batch-operated devices, the comparison is not straightforward. Still, a similar decreasing trend with MCE was observed for NMVOCs. Overall, $50-90 \%$ of the total carbon mass (excluding $\mathrm{CO}_{2}$ ) was emitted as $\mathrm{CO}$, whereas the rest consisted predominately of NMVOCs $(<10 \%$ for automated and $<40 \%$ for batch-operated devices). Overall, higher temperature and MCE resulted in a decrease of the $\mathrm{CO}, \mathrm{CH}_{4}$, and NMVOCs EFs across all devices (Figure 1). In contrast, POA emissions did not show any correlation with MCE or $\lambda$ (Figure 1 and SI Figure S4). Further, $\mathrm{eBC}$ was found less dependent on $\lambda$ and the combustion chamber temperature compared to other gas phase carbonaceous species, while it also followed a decreasing trend with increasing MCE (SI Figure S4).

NO emissions (at temperature $T<1100^{\circ} \mathrm{C}$ ), which originate from organically bound nitrogen present in the fuel, ${ }^{70}$ generally scaled with $\mathrm{CO}_{2}$. The $\mathrm{NO}$ and $\mathrm{CO}_{2}$ concentrations measured in our case are highly correlated, irrespective of the temperature, consistent with the NO formation from fuel degradation. Therefore, NO EFs were relatively stable irrespective of the technology and tidily clustered around $1 \pm 0.3 \mathrm{~g} \mathrm{~kg}^{-1}$ of wood burnt, with a slight decreasing trend with $\lambda$. NO emissions increased by a factor $\sim 3-6$ in device 4 , when wheat pellets were used, potentially due to higher nitrogen content in the fuel (SI Table S1).

3.2. Effect of Stove Technology on Emission Evolution. To understand the effect of technology and combustion phase 
on the emission intensity, we examine in Figure 2 (a-d), the emission evolution (eq 2) per carbon mass fraction consumed across different batch logwood operated technologies. For device 5 and 6, average cumulative EFs of both first load and reload combustion cycles are calculated. Since for these devices, each set of experiment has one first load and 4-6 reloads, the effect of high emissions during first loads due to lower combustion temperature on the averaged cumulative EFs is not dominant (SI Figure S5). In contrast, only a first load condition is shown for device 2 and 7 , as no reloads are possible.

For devices 2, 5, and 6, high emissions occur during the start phase, followed by a moderate increase during the flaming phase and again a pronounced increase at burn-out. Compared to flaming phases, MCE was lower and $\lambda$ higher during start and burn-out phase indicating nonideal combustion conditions. Apart from the MCE defined combustion phases, a similar trend was observed during the combustion phases represented by the carbon mass fraction consumed $(C)$ (where, $C<0.2$ : start phase; $0.2<C<0.8$ : flaming phase and $C>0.8$ : burn-out phase) (SI Figure S5 and Section S3.4). Overall, about $90 \%$ of the emissions were in the start phase in device 2 for $\mathrm{CH}_{4}, \mathrm{eBC}$ and NMVOCs, and $60-75 \%$ in device 5 and 6 for NMVOCs. This is most probably due to the insufficient flue gas temperature to ignite the volatiles released during combustion. Further, increased combustion rate and temperature resulted in lower emissions with distinct NMVOC chemical composition (discussed in Section 3.3) during the flaming phase. CO typically has a higher fractional contribution in the burn-out phase compared to NMVOCs and $\mathrm{CH}_{4}$ possibly due to burning of char with incoming $\mathrm{O}_{2}^{71}$ (SI Figure S5 and S6).

Device 7 , equipped with a storage container, allows the wood logs to slide automatically on the grate with gravity. Consequently, it does not have typical reload conditions as in other logwood stoves; hence, the operation is semicontinuous. In our experiments, the amount of wood burnt in device 7 was $>10 \mathrm{~kg}$ compared to $\sim 2-3 \mathrm{~kg}$ per load typically used in other devices. Therefore, the flaming conditions were extended arbitrarily ( $\sim 90-240 \mathrm{~min}$ in these experiments) compared to other stoves $(\sim 20-60 \mathrm{~min})$. This resulted into relatively constant emissions in all the combustion phases in device 7 (Figure 2d). The fractional contributions of all emissions in the starting phase of device 7 were comparable to the cold start of first loads in old conventional technology (device 5) and lower than the advanced technology (device 2 and 6) (SI Figure S5). Furthermore, emissions increased by a factor of 2 (NMVOCs) and 3-3.5 $\left(\mathrm{CH}_{4}\right.$ and $\left.\mathrm{CO}\right)$ in the flaming phase of device 7 compared to its start phase (SI Figure S5). This was due to the discontinuities occurring while refueling with logs sliding from the log storage tank onto the existing bed of glowing embers.

The comparison between automated and batch-operated devices is not straightforward. Repeated combustion cycles (start, flaming and burn-out phase) in batch-operated devices and extended flaming phase conditions in the automated devices can lead to biased results. Thus, cumulative emissions for batchoperated devices and the averaged combustion-phase specific emissions for automated devices, each normalized to $1 \mathrm{~kg}$ of wood burnt are used for direct comparison (Figure 2e).

Normal/optimum operation conditions of the automated devices 1, 3, and 4 had $\sim 10-1000$ times lower $\mathrm{CH}_{4}$ and NMVOCs emissions compared to the total integrated EFs of the batch-operated devices due to automatic and controlled fuel feeding, and controlled combustion air supply. It should be noted that in the automated devices short start and burn out phases (normally $<5 \mathrm{~min}$ ) have also higher emissions than extended optimum stable conditions, but they are usually still much lower than in the batch-operated devices (e.g., see device 4 in SI Figure S6).

Among batch-operated devices, the total cumulative emissions of device 7 were comparable to device 5 and 2-3 times higher than device 2 and 6 (Figure $2 a-d$ ). Specifically, $\mathrm{CH}_{4}$ and NMVOCs emissions were $\sim 4-6$ and $\sim 4-10$ reduced in device 6 , but up to $\sim 5$ (dry reloads) and $\sim 10-15$ (first loads) times higher POA and $\sim 2$ times higher $\mathrm{eBC}$ was emitted compared to device 5. eBC and POA emissions from automated devices (device 1, 3, and 4) under optimal combustion conditions were lowest, even compared to relatively cleaner flaming phase of the batch-operated devices $(2,5,6$, and 7) (SI Table S3). Device 3 was the cleanest technology among all tested devices for all pollutants followed by device 1 and device 4 operated under optimum conditions.

Partial-load conditions and any deviations from the recommended conditions resulted in enhanced emissions (SI Figure S6). For example, introducing wheat pellets and partialload conditions in automated device 4 increased the emissions of $\mathrm{CH}_{4}$, $\mathrm{CO}$ (by a factor of 1.3 and 16), NO (by a factor of 6 and 1.3), NMVOCs (by a factor of 4.5 and 3.5) and POA (by a factor of 5 and 8). Similarly, enhanced emissions were observed for device 3 when operated in partial-load conditions. The maloperation of automated device 1 under lack of $\mathrm{O}_{2}\left(\lambda_{--}\right)$with $\lambda$ of $1.34 \pm 0.09$ showed $\sim 17$ times higher eBC emissions whereas excess $\mathrm{O}_{2}\left(\lambda_{++}\right)$with $\lambda$ of $3.07 \pm 0.22$ had $\sim 100$ times higher $\mathrm{CO}$, NMVOCs and $\mathrm{CH}_{4}$ emissions compared to its optimum conditions (Figure 2e and SI Table S3). Furthermore, using wet wood logs in batch-operated devices also increased the emissions with highest intensity in device 2 . This is due to a reduced temperature due to water evaporation and therefore incomplete combustion. ${ }^{72-74}$ The emission factors have been observed to increase nonlinearly with fuel moisture. ${ }^{75}$ The flaming phase in device 2 had enhanced emissions of $\mathrm{CH}_{4}$, NMVOCs, CO, and eBC, compared to the undisturbed dry flaming phase (more than a factor of $\sim 100,8,15$, and 6 , respectively). $\mathrm{CH}_{4}, \mathrm{CO}$, and eBC emissions in semicontinuously operated device 7 increased only by a factor $\sim 2-3$ during the flaming phase and NMVOCs by $\sim 6$ times in the burn-out phase. Device 5 and 6 , when operated with wet wood logs over a complete cycle, emitted doubled $\mathrm{CO}$, and tripled $\mathrm{CH}_{4}$. Comparatively, NMVOCs were only increased in device 6 by a factor of 1.5 but not in device 5 . In both devices, no significant changes in eBC using wet logs were observed (SI Figure S6). Further, overloading the combustion chamber of device 6 also enhanced all the emissions (SI Figure S6 and Table S3).

Lastly, we compare the average $\mathrm{CO}, \mathrm{CH}_{4}, \mathrm{POA}$ or OC, NMVOCs, and eBC EFs literature values between residential heating (masonry heater ${ }^{41}$ and conventional stoves; ${ }^{17,37,43} \mathrm{MCE}$ $=0.8-0.97)$ and field fires ${ }^{13,14,27,64,76}(\mathrm{MCE}=0.93-0.98)$ with this study to provide a perspective on their relative contributions. The laboratory studies have limitations in explaining the observed variability in the field emissions due to their inability to simulate driving parameters such as wind speed, fire spread area and varying moisture content. ${ }^{77}$ Despite of these limitations, they are advantageous in characterizing the full cycle of emissions more accurately using different fuel composition and combustion conditions by using extensive instrumentation. $^{13,27}$ These previously reported EFs were comparable for residential heating and field fires, while their

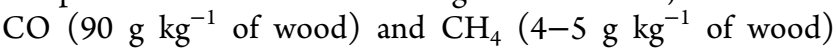




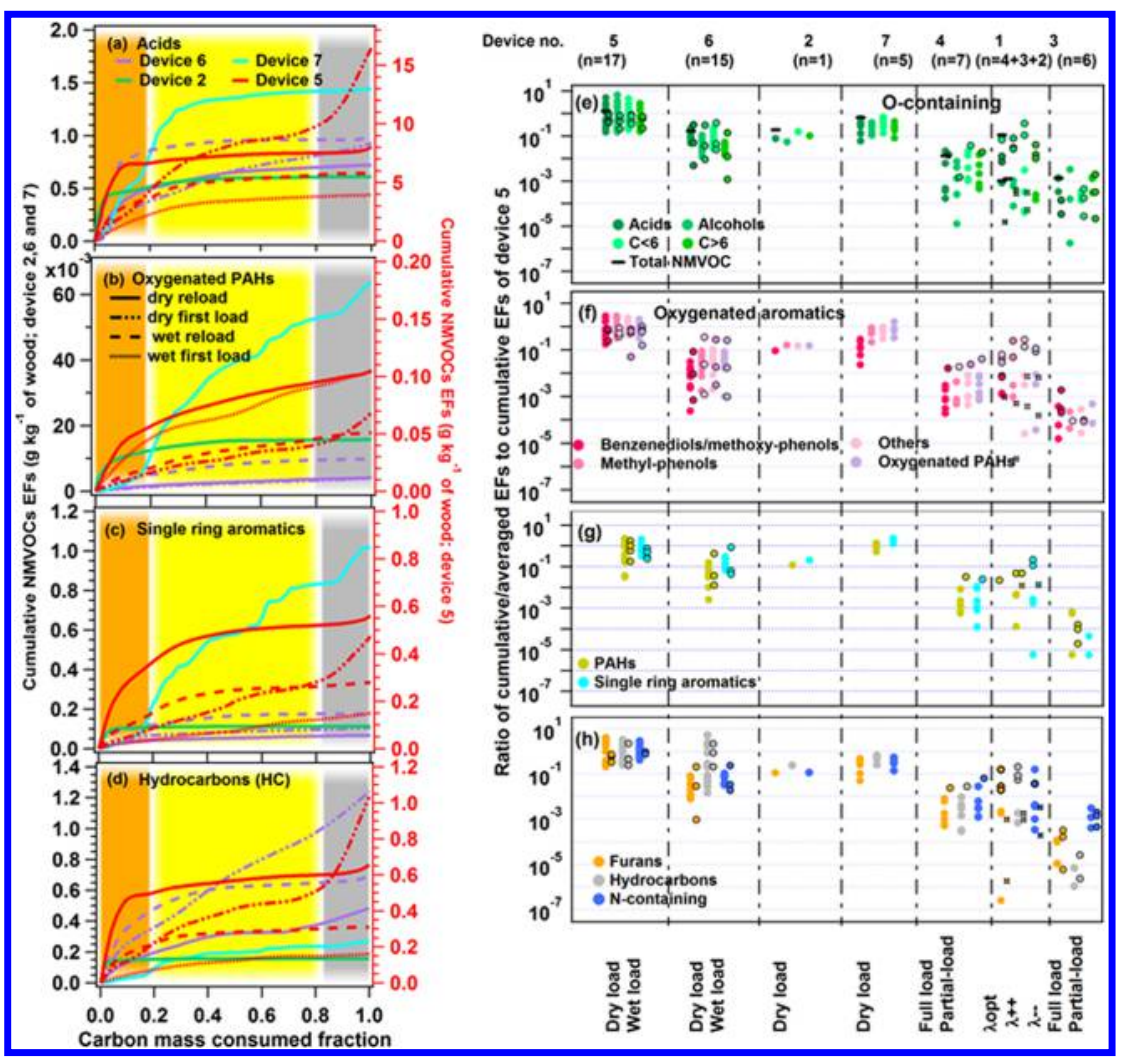

Figure 3. (a-d) Averaged cumulative EFs ( $\mathrm{g} \mathrm{kg}^{-1}$ of wood) of representative NMVOC classes from batch-operated devices (2, 5, 6, and 7). The orange, yellow and gray shaded areas represent start, flaming and burn-out phase, respectively. EFs of the remaining classes are given in SI Figure S8. $(\mathrm{e}-\mathrm{h})$ Ratios of cumulative EFs (at 100\% carbon mass consumed) of classified NMVOC species from different batch-operated devices $(2,5,6$, and 7$)$ and averaged EFs from the flaming phase of automated devices $(1,3$, and 4$)$, where all data points are normalized to dry reload conditions of the conventional stove (device 5) to demonstrate the effect of the advanced technologies on NMVOC emissions. Filled markers represent dry first loads and reloads from batch-operated devices and optimum condition of device 1, whereas open markers represent wet first loads and reloads from batchoperated devices, $\lambda_{++}$condition of device 1 and partial-load conditions of device 3. Squared markers represent $\lambda_{--}$conditions of device 1 . The solid black bar presents the averaged ratio for total cumulative NMVOCs. $\mu \pm 1 \sigma$ values (where, $\mu$ is average and $\sigma$ is standard deviation) of the ratios from only dry first loads and reloads are provided in SI Table S4 for reference.

emissions are 2-3 times higher compared to old stove technology device 5 of the current study (Figure 2e and SI Figure S7). The POA or OC emissions from laboratory and field fires are 1-3 orders of magnitude higher compared to the residential heating in past and the present study (SI Figure S7 and 1c). Further, comparing residential wood combustion emissions, the NMVOCs EFs for log wood stoves reported in the literature $\left(\sim 13 \pm 13.5 \mathrm{~g} \mathrm{~kg}^{-1}\right.$ of wood) were lower compared to the ones $\left(19 \pm 15 \mathrm{~g} \mathrm{~kg}^{-1}\right.$ of wood) tested in this study. This is due to consideration of only stable combustion phase emissions in those studies and possibly due to different combustion procedures, ${ }^{41}$ where a new batch of logs was injected after every half an hour. Literature values of eBC emissions from residential heating devices were higher compared to our study (up to $\sim 3$ orders of magnitude for batch-operated devices and 10 times for pellet operated devices).

3.3. NMVOCs Chemical Composition and Their Combustion Evolution. In this section, we discuss the emission intensity, variability and possible origin of dominating NMVOCs classes along with the exceptions, if any, with the evolution of combustion cycle of batch-operated devices (Figure $3(\mathrm{a}-\mathrm{d})$ and SI Figure S8). Later, we evaluate the performance of conventional and advanced combustion technologies.

Highest emissions in logwood stoves were mainly from first loads and start phases of reloads, and were mainly composed of small oxygenated NMVOCs (small carbonyls and acids, and furans), for example, acetaldehyde, formaldehyde, and acetic acid. Overall, O-containing_acids (29-34\%) and C $<6$ ( 23$29 \%$ ) were the two most abundant classes contributing to the total signal of a combustion cycle followed by furans $(8-11 \%)$ and alcohols (8-13\%) (SI Table S5). Bruns et al. (2017) observed similar contributions of the main classes such as acids, furans and alcohols, but a $3 \times$ higher contribution from SRA, from a logwood stove. Similarly, McDonald et al. ${ }^{37}$ also reported a higher SRA contribution in addition to high alcohol contribution $(\sim 30 \%)$ for hardwood combusted in a woodstove. Here, acetic acid was consistently the dominant carboxylic acid $(60-95 \%)$ followed by formic acid $(\leq 5 \%)$ in the $\mathrm{O}$ containing_acids class. About $\sim 99 \%$ of the alcohols were comprised of methanol, which originates from the lignin (methoxyl groups cleavage) and hemicellulose (methyl-uronic acid units) decomposition. ${ }^{32,37,78}$ Products of cellulose pyrolysis $^{78}$ like acetaldehyde, formaldehyde constitute the main fraction of the $C<6$ class $(\leq 50 \%)$, while decomposition of cellulose followed by dehydration forms furans with 2furaldehyde (furfural)/furan-2-carbaldehyde contributing up to $\sim 52 \%$. The other less dominating NMVOCs classes such as Ocontaining_C $>6$, oxygenated aromatics_benzenediols/methoxy-phenols and SRA increased with the evolution of combustion cycle and is in line with the observation of Sekimoto et al., ${ }^{67}$ where "high- $\left(500-800{ }^{\circ} \mathrm{C}\right)$ " temperature pyrolysis (e.g., depolymerization, fragmentation, and aromatization) led 
to short and nonsubstituted aromatics and polycyclic aromatics (phenols, benzene, and PAHs) and "low-temperature $(<500$ $\left.{ }^{\circ} \mathrm{C}\right)$ " reactions resulted in furans and benzenediols/methylphenols class emissions. However, the dominating classes such as acids and small carbonyls were emitted independent of the combustion temperature. Other classes like PAHs, and oxygenated aromatics_methylphenols and oxygenated PAHs showed device-specific emission trends.

Similar to Figure 2, we show variability in the emissions of NMVOCs classes with the evolution of the combustion cycle in Figure 3(a-d) and SI Figure S8 for the batch-operated devices $(2,5,6$, and 7$)$. As mentioned above, up to $90 \%$ of the NMVOCs emissions occurred in the start phase in device 2,5 , and 6 . Dry and wet reload conditions in device 5 show the main emissions in the start phase for acids, alcohols, $C<6$, SRA, HC, and furans, whereas the other classes further increase during the flaming and burn-out phases. It is noteworthy that the burn-out phase of first dry loads has higher emission of acids, furans, SRA and $\mathrm{HC}$ while wet loads have higher alcohols, $C<6$ and oxygenated aromatics. In device 6 , the main emission of all classes occurs in the start phase for first dry load as well as dry and wet reload. The only exception is the continuous emission of $\mathrm{HC}$ over all phases in first dry load. The evolution of emissions in device 7 is similar to device 5 but the plateau of acids, alcohols, $C<6$, HC and furans is only reached after $\sim 35 \%$ of carbon mass consumed. Emissions of all other classes continue to increase. Some of these, for example, SRA and oxygenated aromatics, have a high SOA forming potential. Conclusively, the overall emissions are dominated by the start phase with high acids and $C<6$, but first loads and wet wood leads to specifically different contributions and evolutions of the classes at any stage of the combustion cycle.

To evaluate the performance of the tested combustion devices, we compare the emission factors of the various NMVOCs classes of device 5 (representative of widely used conventional single-stage combustion technology) to different combustion conditions of all the other devices. Figure $3 \mathrm{e}-\mathrm{h}$ (SI Table S4) shows the ratios of flaming phase specific EFs (for automated devices) or cumulative EFs (batch-operated devices) to the cumulative EF of device 5 under dry reload conditions. Similar to total NMVOCs, all classes have EFs that are lower by orders of magnitude for the automated devices. In the past, smaller differences in the emission levels of small carbonyls (i.e., acetaldehyde and formaldehyde) and even similar levels for other species (i.e, butanal, propanal, hexanal, methacrolein, etc.) were reported ${ }^{42}$ by comparing an automated combustion device (pellet boiler) and a masonry heater. Since the O-containing class contributes $60-80 \%$ to total NMVOCs, the ratio of acids, alcohols, $C<6$ and $C>6$ in all devices compared to device 5 scales roughly with the ratio of total NMVOCs (Figure 3e). The other classes were also reduced with different intensity and few exceptions. For example, in device 3, SRA, furans and hydrocarbons are by orders of magnitude more reduced than total NMVOCs and the O-containing class. On the other hand, emissions of SRA, PAHs and oxygenated PAHs in batchoperated device 7 are similar to those in device 5 while total NMVOCs is reduced by a factor of 2 . This shows that devices with advanced technologies do not necessarily eliminate the problems arising from specific NMVOCs emissions. Despite a reduction of total NMVOCs, some critical compounds may not or only slightly be reduced keeping these devices still as a challenge for their use in the real world. Further, nonideal operation of device $1\left(\lambda_{++}\right)$increased the emissions of all
NMVOCs classes to levels comparable to device 6. The combustion of wet wood (open symbols) in reloads and first load conditions increased all NMVOCs classes in device 6 but decreased them in device 5 (by $\sim 50 \%$; except for PAHs).

3.4. NMVOC Species Variability with Combustion Conditions. NMVOCs fingerprints and their individual combustion phase-specific emission intensities were highly variable. As the data does not follow the normal distribution, rank transformation is applied before ANOVA (analysis of variance) analysis. Only a minor fraction of this variability could be explained by categorizing the data according to the differences in technology $(22 \%)$ or together with the combustion phase information (12\%). In contrast to the total NMVOCs EFs (shown in Figure 1), the EFs of individual compounds were only weakly dependent on MCE, ${ }^{79} \lambda$ or the combustion temperature. However, recently, Sekimoto et al. ${ }^{67}$ observed that combustion temperature is a better predictor of variability in open biomass burning NMVOCs emission profiles compared to MCE defined combustion phases. Our observations indicate that several parameters may concomitantly drive the overall variability observed in the NMVOCs chemical composition, and consequently, in this section we examine these parameters.

Using 2D-HCA clustering analysis, the NMVOCs emissions could be classified into three major groups according to their composition (Figure $4 \mathrm{~b}$ and $\mathrm{c}$ ) and emission intensity (Figure 4a; also see SI Figure S9a for 2D-HCA analysis and SI Table S6 for more explanation). Decision tree classification algorithms further assisted in separation into groups and subgroups constituted on the basis of (1) combustion parameters, including device and load type (first load/reload), combustion phase, and conventional gas phase emissions (e.g., $\mathrm{CO}$ and $\mathrm{CH}_{4}$ ) and (2) main NMVOCs emitted.

Group I exhibited high combustion phase-specific emissions of $\mathrm{CH}_{4}\left(\sim 1 \mathrm{~g} \mathrm{~kg}^{-1}\right.$ of wood) and total NMVOCs $\left(\sim 3 \mathrm{~g} \mathrm{~kg}^{-1}\right.$ of wood) (Figure $4 \mathrm{a}$ and SI Figure S10b). Emissions were characterized by the relatively higher contribution of small oxygenated molecules, with acetic acid, propen-2-al, methyl vinyl ketone, acetaldehyde, methanol and formaldehyde as major species (Figure 4c). In contrast, Group II had low $\mathrm{CH}_{4}$ $\left(0.10 \mathrm{~g} \mathrm{~kg}^{-1}\right.$ of wood) and total NMVOCs $\left(\sim 0.3 \mathrm{~g} \mathrm{~kg}^{-1}\right.$ of wood) emissions. Group III featured similar levels of $\mathrm{CH}_{4}$ and NMVOCs as Group I but the NMVOCs emission profiles were significantly different. Emissions in Group III were characterized by the high abundance of HC ( $\sim 24 \%$, compared to Group II [8.5\%] and Group I [5\%]) and higher molecular weight aliphatic oxygenated molecules ( $\sim 7 \%$ compared to Groups I and II $[<2 \%]$ ) together with $\mathrm{N}$-containing compounds (Figure $4 \mathrm{~b}$ and 4c). Clustering enabled classifying very similar emission profiles $(R>0.6$ in each class, SI Figure S9c) into two distinct groups, Group I and III, while emission profiles classified in Group II were more variable ( $R \sim 0.4$, SI Figure S9c). Such grouping was not possible when the effects of single combustion parameters on the emissions were examined.

Emissions from first loads and start phases of reloads were strictly classified in Group I (Figure 4d, SI Table S6) and characterized by high emissions of oxygenated NMVOCs (small aldehydes and acids, furans, and oxygenated aromatics). The significantly lower emissions from the burn-out phases were classified into Group II, with few exceptions of device 5 (conventional technology; Figure $4 \mathrm{a}$ and $\mathrm{d}$ ). Flaming phase emissions from all devices were distributed among both groups (I and II), depending on the combustion conditions. High 


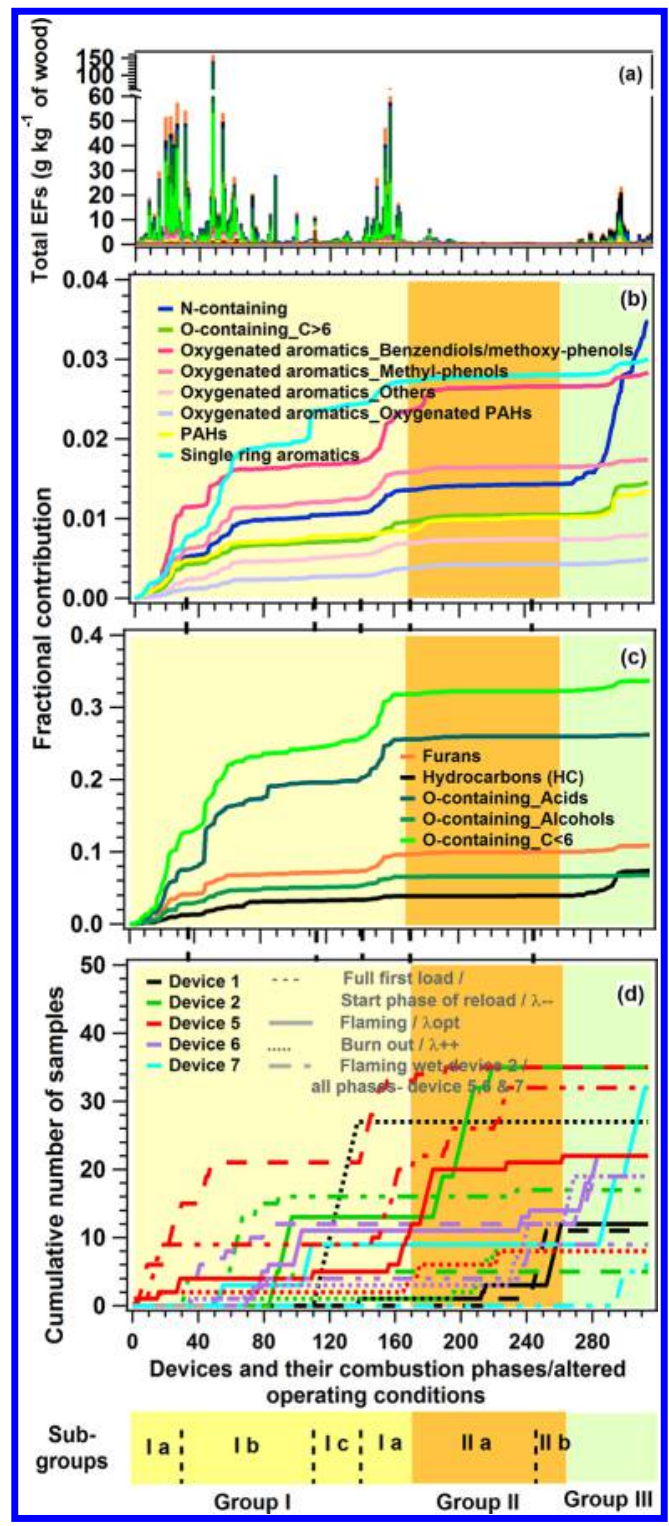

Figure 4. (a) Total EFs corresponding to a single combustion phase/ altered condition event from an individual device ( $x$-axis), (b and c) fractional contribution of each NMVOCs class, and (d) cumulative number of samples/events over each device and combustion phase among different groups and further distinguished subgroups. The yellow, orange and green shaded areas represent Group I, Group II, and Group III, respectively.

emissions of oxygenated NMVOCs were observed during the flaming phases, when wet wood was used and when combustion temperature was lower. Emission profiles in Group III were characteristic of advanced wood stoves equipped with two-stage combustion technologies, especially emissions from device 7 , revealing a clear dependence of the emission profiles on the technology used (Figure 4d). Further, Group I could also be further broken down into three different subgroups according to the technology. The start phases in the conventional (device 5) and the advanced wood stove (device 6) together with the logwood operated boiler (device 2) were classified into class Ia and $\mathrm{Ib}$, respectively, because of their significantly higher benzenediols/methoxy-phenols emissions in the former (SI Figure S8). Emission profiles of the pellet boiler (device 1) were classified in the subgroup Ic and IIb, and were clearly distinguished from those of wood stoves ( $\mathrm{Ia}$ and $\mathrm{Ib}$ ) by the lack of a large number of hydrocarbon species, including alkenes/alkynes, PAHs $\left(C_{n}>11\right)$ and SRA $\left(C_{n}>8\right)$ as well as oxygenated aromatics $\left(C_{n}>7\right.$ or 8$)$. When this device was operated under excess of $\mathrm{O}_{2}$ conditions $\left(\lambda_{++}\right)$, significant emissions of oxygenated NMVOCs were generated, resulting in the classification of these emissions into subgroup Ic (Figure 4 ). When this device was operated under optimal or fuel-rich combustion conditions ( $\lambda_{\text {opt }}$ and $\lambda_{--}$, respectively), emission profiles were distinctively classified into subgroup IIb due to lower emissions. The other lower emission profiles in Group II (IIa) from other devices (2, 5, and 6) are related to optimal flaming and burn-out conditions.

The clustering revealed the unperceived differences between the emission fingerprints and could help relating these fingerprints to the combustion conditions classified into three groups with high and low $\mathrm{CH}_{4}$ and total NMVOCs emissions (SI Figure S9b). This suggests that $\mathrm{CH}_{4}$ can be used as an indicator for near-complete and in-complete combustion emissions, where at high $\mathrm{CH}_{4}$ levels the chemical composition of the emissions may significantly differ. Under those conditions, we need detailed chemical composition to predict the burden, the fate and the impacts of the emissions on the atmosphere.

\section{ASSOCIATED CONTENT}

\section{Supporting Information}

The Supporting Information is available free of charge on the ACS Publications website at DOI: 10.1021/acs.est.8b05020.

Details on wood combustion devices, sampling procedure and instrumentation, data analysis, fuel properties, specifications of combustion devices, cluster analysis, cumulative NMVOC EFs, fractional contribution of classified NMVOCs to the total NMVOC EFs, schematic of instrumental setup, transmission function of PTRTOF-MS, inconsistency coefficient in 2D-HCA, combustion phase-specific EFs of gas and particle phase species, evolution of EFs along the combustion cycle, comparison of averaged EFs among different technologies and operating conditions, comparison with literature studies, comparison of evolution of NMVCOs among different technologies, 2D-HCA dendrogram and EFs among different groups (PDF)

Averaged EFs (conventional gas phase species and NMVOCs) (XLSX)

\section{AUTHOR INFORMATION}

\section{Corresponding Authors}

*(D.B.) E-mail: deepika.bhattu@psi.ch.

*(J.D.) E-mail: josef.dommen@psi.ch.

\section{ORCID}

Deepika Bhattu: 0000-0003-3597-190X

Peter Zotter: 0000-0002-9274-9662

André Stephan Henry Prévôt: 0000-0002-9243-8194

Imad El Haddad: 0000-0002-2461-7238

Josef Dommen: 0000-0002-0006-0009

\section{Present Address}

"(J.Z.) Graduate School of Global Environmental Studies, Kyoto University, Kyoto, 606-8501, Japan.

\section{Notes}

The authors declare no competing financial interest. 


\section{ACKNOWLEDGMENTS}

This study was financially supported by Swiss National Science Foundation (NRP 70 "Energy Turnaround"), the European Union's Horizon 2020 research and innovation programme through the EUROCHAMP-2020 Infrastructure Activity under grant agreement no. 730997, and the Swiss Competence Centre for Energy Research SCCER BIOSWEET of the Swiss Innovation Agency Innosuisse.

\section{REFERENCES}

(1) https://www.eia.gov/outlooks/ieo/exec summ.php (accessed September 14, 2017).

(2) Johansson, L. S.; Leckner, B.; Gustavsson, L.; Cooper, D.; Tullin, C.; Potter, A. Emission characteristics of modern and old-type residential boilers fired with wood logs and wood pellets. Atmos. Environ. 2004, 38 (25), 4183-4195.

(3) Glasius, M.; Ketzel, M.; Wåhlin, P.; Jensen, B.; Mønster, J.; Berkowicz, R.; Palmgren, F. Impact of wood combustion on particle levels in a residential area in Denmark. Atmos. Environ. 2006, 40 (37), $7115-7124$.

(4) Szidat, S.; Prévôt, A. S. H.; Sandradewi, J.; Alfarra, M. R.; Synal, H.A.; Wacker, L.; Baltensperger, U. Dominant impact of residential wood burning on particulate matter in Alpine valleys during winter. Geophvs. Res. Lett. 2007, 34 (5), 1-6.

(5) Bond, T. C.; Doherty, S. J.; Fahey, D. W.; Forster, P. M.; Berntsen, T.; DeAngelo, B. J.; Flanner, M. G.; Ghan, S.; Kärcher, B.; Koch, D.; Kinne, S.; Kondo, Y.; Quinn, P. K.; Sarofim, M. C.; Schultz, M. G.; Schulz, M.; Venkataraman, C.; Zhang, H.; Zhang, S.; Bellouin, N.; Guttikunda, S. K.; Hopke, P. K.; Jacobson, M. Z.; Kaiser, J. W.; Klimont, Z.; Lohmann, U.; Schwarz, J. P.; Shindell, D.; Storelvmo, T.; Warren, S. G.; Zender, C. S. Bounding the role of black carbon in the climate system: A scientific assessment. L. Geophys. Res. Atmospheres 2013, 118 (11), 5380-5552.

(6) Hodnebrog, Ø.; Myhre, G.; Samset, B. H. How shorter black carbon lifetime alters its climate effect. Nat. Commun. 2014, 5, 1-7.

(7) Leonard, S. S.; Wang, S.; Shi, X.; Jordan, B. S.; Castranova, V.; Dubick, M. A. Wood smoke particles generate free radicals and cause lipid peroxidation, DNA damage, $\mathrm{NF} \kappa \mathrm{B}$ activation and TNF- $\alpha$ release in macrophages. Toxicology 2000, 150 (1), 147-157.

(8) Leonard, S. S.; Castranova, V.; Chen, B. T.; Schwegler-Berry, D.; Hoover, M.; Piacitelli, C.; Gaughan, D. M. Particle size-dependent radical generation from wildland fire smoke. Toxicology 2007, 236 (1), $103-113$.

(9) Kocbach, A.; Namork, E.; Schwarze, P. E. Pro-inflammatory potential of wood smoke and traffic-derived particles in a monocytic cell line. Toxicology 2008, 247 (2), 123-132.

(10) Danielsen, P. H.; Loft, S.; Kocbach, A.; Schwarze, P. E.; Møller, P. Oxidative damage to DNA and repair induced by Norwegian wood smoke particles in human A549 and THP-1 cell lines. Mutat. Res., Genet. Toxicol. Environ. Mutagen. 2009, 674 (1-2), 116-122.

(11) Miljevic, B.; Heringa, M. F.; Keller, A.; Meyer, N. K.; Good, J.; Lauber, A.; DeCarlo, P. F.; Fairfull-Smith, K. E.; Nussbaumer, T.; Burtscher, H.; Prevot, A. S. H.; Baltensperger, U.; Bottle, S. E.; Ristovski, Z. D. Oxidative potential of logwood and pellet burning particles assessed by a novel profluorescent nitroxide probe. Environ. Sci. Technol. 2010, 44 (17), 6601-6607.

(12) Guenther, A. B.; Jiang, X.; Heald, C. L.; Sakulyanontvittaya, T.; Duhl, T.; Emmons, L. K.; Wang, X. The Model of Emissions of Gases and Aerosols from Nature version 2.1 (MEGAN2.1): an extended and updated framework for modeling biogenic emissions. Geosci. Model Dev. 2012, 5 (6), 1471-1492.

(13) Yokelson, R. J.; Burling, I. R.; Gilman, J. B.; Warneke, C.; Stockwell, C. E.; de Gouw, J.; Akagi, S. K.; Urbanski, S. P.; Veres, P.; Roberts, J. M.; Kuster, W. C.; Reardon, J.; Griffith, D. W. T.; Johnson, T. J.; Hosseini, S.; Miller, J. W.; Cocker Iii, D. R.; Jung, H.; Weise, D. R. Coupling field and laboratory measurements to estimate the emission factors of identified and unidentified trace gases for prescribed fires. Atmos. Chem. Phys. 2013, 13 (1), 89-116.
(14) Christian, T. J.; Kleiss, B.; Yokelson, R. J.; Holzinger, R.; Crutzen, P. J.; Hao, W. M.; Saharjo, B. H.; Ward, D. E. Comprehensive laboratory measurements of biomass-burning emissions: 1 . Emissions from Indonesian, African, and other fuels. I. Geophys. Res. 2003, 108 (D23), 1-13.

(15) Warneke, C.; Roberts, J. M.; Veres, P.; Gilman, J.; Kuster, W. C.; Burling, I.; Yokelson, R.; de Gouw, J. A. VOC identification and intercomparison from laboratory biomass burning using PTR-MS and PITMS. Int. I. Mass Spectrom. 2011, 303 (1), 6-14.

(16) Hatch, L. E.; Luo, W.; Pankow, J. F.; Yokelson, R. J.; Stockwell, C. E.; Barsanti, K. C. Identification and quantification of gaseous organic compounds emitted from biomass burning using two-dimensional gas chromatography-time-of-flight mass spectrometry. Atmos. Chem. Phys. 2015, 15 (4), 1865-1899.

(17) Bruns, E. A.; Krapf, M.; Orasche, J.; Huang, Y.; Zimmermann, R.; Drinovec, L.; Močnik, G.; El-Haddad, I.; Slowik, J. G.; Dommen, J.; Baltensperger, U.; Prévôt, A. S. H. Characterization of primary and secondary wood combustion products generated under different burner loads. Atmos. Chem. Phys. 2015, 15 (5), 2825-2841.

(18) Jathar, S. H.; Gordon, T. D.; Hennigan, C. J.; Pye, H. O. T.; Pouliot, G.; Adams, P. J.; Donahue, N. M.; Robinson, A. L. Unspeciated organic emissions from combustion sources and their influence on the secondary organic aerosol budget in the United States. Proc. Natl. Acad. Sci. U. S. A. 2014, 111 (29), 10473-10478.

(19) Grieshop, A. P.; Donahue, N. M.; Robinson, A. L. Laboratory investigation of photochemical oxidation of organic aerosol from wood fires 2: analysis of aerosol mass spectrometer data. Atmos. Chem. Phvs. 2009, 9 (6), 2227-2240.

(20) Tkacik, D. S.; Robinson, E. S.; Ahern, A.; Saleh, R.; Stockwell, C.; Veres, P.; Simpson, I. J.; Meinardi, S.; Blake, D. R.; Yokelson, R. J.; Presto, A. A.; Sullivan, R. C.; Donahue, N. M.; Robinson, A. L. A dualchamber method for quantifying the effects of atmospheric perturbations on secondary organic aerosol formation from biomass burning emissions. I. Geophvs. Res. Atmospheres 2017, 122 (11), 60436058.

(21) Crutzen, P. J.; Andreae, M. O. Biomass Burning in the Tropics: Impact on Atmospheric Chemistry and Biogeochemical Cycles. Science 1990, 250 (4988), 1669-1678.

(22) Trentmann, J.; Yokelson, R. J.; Hobbs, P. V.; Winterrath, T.; Christian, T. J.; Andreae, M. O.; Mason, S. A. An analysis of the chemical processes in the smoke plume from a savanna fire. I. Geophvs. Res. 2005, 110 (D12), 1-20.

(23) Alvarado, M. J.; Prinn, R. G. Formation of ozone and growth of aerosols in young smoke plumes from biomass burning: 1. Lagrangian parcel studies. J. Geophys. Res. 2009, 114 (D9), 1-19.

(24) Yokelson, R. J.; Crounse, J. D.; DeCarlo, P. F.; Karl, T.; Urbanski, S.; Atlas, E.; Campos, T.; Shinozuka, Y.; Kapustin, V.; Clarke, A. D.; Weinheimer, A.; Knapp, D. J.; Montzka, D. D.; Holloway, J.; Weibring, P.; Flocke, F.; Zheng, W.; Toohey, D.; Wennberg, P. O.; Wiedinmyer, C.; Mauldin, L.; Fried, A.; Richter, D.; Walega, J.; Jimenez, J. L.; Adachi, K.; Buseck, P. R.; Hall, S. R.; Shetter, R. Emissions from biomass burning in the Yucatan. Atmos. Chem. Phvs. 2009, 9 (15), 5785-5812.

(25) Vakkari, V.; Kerminen, V.-M.; Beukes, J. P.; Tiitta, P.; van Zyl, P. G.; Josipovic, M.; Venter, A. D.; Jaars, K.; Worsnop, D. R.; Kulmala, M.; Laakso, L. Rapid changes in biomass burning aerosols by atmospheric oxidation. Geophys. Res. Lett. 2014, 41 (7), 2644-2651.

(26) Yokelson, R. J.; Griffith, D. W. T.; Ward, D. E. Open-path Fourier transform infrared studies of large-scale laboratory biomass fires. $I$. Geophys. Res. Atmospheres 1996, 101 (D15), 21067-21080.

(27) Burling, I. R.; Yokelson, R. J.; Griffith, D. W. T.; Johnson, T. J.; Veres, P.; Roberts, J. M.; Warneke, C.; Urbanski, S. P.; Reardon, J.; Weise, D. R.; Hao, W. M.; de Gouw, J. Laboratory measurements of trace gas emissions from biomass burning of fuel types from the southeastern and southwestern United States. Atmos. Chem. Phys. 2010, 10 (22), 11115-11130.

(28) Veres, P.; Roberts, J. M.; Burling, I. R.; Warneke, C.; de Gouw, J.; Yokelson, R. J. Measurements of gas-phase inorganic and organic acids from biomass fires by negative-ion proton-transfer chemical-ionization mass spectrometry. I. Geophvs. Res. 2010, 115 (D23), 1-15. 
(29) Brilli, F.; Gioli, B.; Ciccioli, P.; Zona, D.; Loreto, F.; Janssens, I. A.; Ceulemans, R. Proton Transfer Reaction Time-of-Flight Mass Spectrometric (PTR-TOF-MS) determination of volatile organic compounds (VOCs) emitted from a biomass fire developed under stable nocturnal conditions. Atmos. Environ. 2014, 97 (Supplement C), 54-67.

(30) Gilman, J. B.; Lerner, B. M.; Kuster, W. C.; Goldan, P. D.; Warneke, C.; Veres, P. R.; Roberts, J. M.; de Gouw, J. A.; Burling, I. R.; Yokelson, R. J. Biomass burning emissions and potential air quality impacts of volatile organic compounds and other trace gases from fuels common in the US. Atmos. Chem. Phvs. 2015, 15 (24), 13915-13938.

(31) Stockwell, C. E.; Veres, P. R.; Williams, J.; Yokelson, R. J. Characterization of biomass burning emissions from cooking fires, peat, crop residue, and other fuels with high-resolution proton-transferreaction time-of-flight mass spectrometry. Atmos. Chem. Phvs. 2015, 15 (2), $845-865$.

(32) McKenzie, L. M.; Hao, W. M.; Richards, G. N.; Ward, D. E. Measurement and Modeling of Air Toxins from Smoldering Combustion of Biomass. Environ. Sci. Technol. 1995, 29 (8), 20472054.

(33) Hennigan, C. J.; Miracolo, M. A.; Engelhart, G. J.; May, A. A.; Presto, A. A.; Lee, T.; Sullivan, A. P.; McMeeking, G. R.; Coe, H.; Wold, C. E.; Hao, W. M.; Gilman, J. B.; Kuster, W. C.; de Gouw, J.; Schichtel, B. A.; Collett, J. L., Jr; Kreidenweis, S. M.; Robinson, A. L. Chemical and physical transformations of organic aerosol from the photo-oxidation of open biomass burning emissions in an environmental chamber. Atmos. Chem. Phys. 2011, 11 (15), 7669-7686.

(34) Ortega, A. M.; Day, D. A.; Cubison, M. J.; Brune, W. H.; Bon, D.; de Gouw, J. A.; Jimenez, J. L. Secondary organic aerosol formation and primary organic aerosol oxidation from biomass-burning smoke in a flow reactor during FLAME-3. Atmos. Chem. Phvs. 2013, 13 (22), 11551-11571.

(35) Cubison, M. J.; Ortega, A. M.; Hayes, P. L.; Farmer, D. K.; Day, D.; Lechner, M. J.; Brune, W. H.; Apel, E.; Diskin, G. S.; Fisher, J. A.; Fuelberg, H. E.; Hecobian, A.; Knapp, D. J.; Mikoviny, T.; Riemer, D.; Sachse, G. W.; Sessions, W.; Weber, R. J.; Weinheimer, A. J.; Wisthaler, A.; Jimenez, J. L. Effects of aging on organic aerosol from open biomass burning smoke in aircraft and laboratory studies. Atmos. Chem. Phys. 2011, 11 (23), 12049-12064.

(36) Zhou, J.; Zotter, P.; Bruns, E. A.; Stefenelli, G.; Bhattu, D.; Brown, S.; Bertrand, A.; Marchand, N.; Lamkaddam, H.; Slowik, J. G.; Prévôt, A. S. H.; Baltensperger, U.; Nussbaumer, T.; El-Haddad, I.; Dommen, J. Particle-bound reactive oxygen species (PB-ROS) emissions and formation pathways in residential wood smoke under different combustion and aging conditions. Atmos. Chem. Phvs. 2018, 18 (10), 6985-7000.

(37) McDonald, J. D.; Zielinska, B.; Fujita, E. M.; Sagebiel, J. C.; Chow, J. C.; Watson, J. G. Fine particle and gaseous emission rates from residential wood combustion. Environ. Sci. Technol. 2000, 34 (11), 2080-2091.

(38) Schauer, J. J.; Kleeman, M. J.; Cass, G. R.; Simoneit, B. R. T. Measurement of Emissions from Air Pollution Sources. 3. C1-C29 Organic Compounds from Fireplace Combustion of Wood. Environ. Sci. Technol. 2001, 35 (9), 1716-1728.

(39) Hedberg, E.; Kristensson, A.; Ohlsson, M.; Johansson, C.; Johansson, P.-A.; Swietlicki, E.; Vesely, V.; Wideqvist, U.; Westerholm, R. Chemical and physical characterization of emissions from birch wood combustion in a wood stove. Atmos. Environ. 2002, 36 (30), 4823-4837.

(40) Mazzoleni, L. R.; Zielinska, B.; Moosmüller, H. Emissions of Levoglucosan, Methoxy Phenols, and Organic Acids from Prescribed Burns, Laboratory Combustion of Wildland Fuels, and Residential Wood Combustion. Environ. Sci. Technol. 2007, 41 (7), 2115-2122.

(41) Reda, A. A.; Czech, H.; Schnelle-Kreis, J.; Sippula, O.; Orasche, J.; Weggler, B.; Abbaszade, G.; Arteaga-Salas, J. M.; Kortelainen, M.; Tissari, J.; Jokiniemi, J.; Streibel, T.; Zimmermann, R. Analysis of gasphase carbonyl compounds in emissions from modern wood combustion appliances: Influence of wood type and combustion appliance. Energy Fuels 2015, 29 (6), 3897-3907.
(42) Bruns, E. A.; El Haddad, I.; Slowik, J. G.; Kilic, D.; Klein, F.; Baltensperger, U.; Prévôt, A. S. H. Identification of significant precursor gases of secondary organic aerosols from residential wood combustion. Sci. Rep. 2016, 6, 1-9.

(43) Bruns, E. A.; Slowik, J. G.; El Haddad, I.; Kilic, D.; Klein, F.; Dommen, J.; Temime-Roussel, B.; Marchand, N.; Baltensperger, U.; Prévôt, A. S. H. Characterization of gas-phase organics using proton transfer reaction time-of-flight mass spectrometry: fresh and aged residential wood combustion emissions. Atmos. Chem. Phvs. 2017, 17 (1), 705-720.

(44) Hawthorne, S. B.; Krieger, M. S.; Miller, D. J.; Mathiason, M. B. Collection and quantitation of methoxylated phenol tracers for atmospheric pollution from residential wood stoves. Environ. Sci. Technol. 1989, 23 (4), 470-475.

(45) Bertrand, A.; Stefenelli, G.; Bruns, E. A.; Pieber, S. M.; TemimeRoussel, B.; Slowik, J. G.; Prévôt, A. S. H.; Wortham, H.; El Haddad, I.; Marchand, N. Primary emissions and secondary aerosol production potential from woodstoves for residential heating: Influence of the stove technology and combustion efficiency. Atmos. Environ. 2017, 169, 6579.

(46) Bertrand, A.; Stefenelli, G.; Jen, C. N.; Pieber, S. M.; Bruns, E. A.; Temime-Roussel, B.; Slowik, J. G.; Goldstein, A. H.; El Haddad, I.; Baltensperger, U.; Prévôt, A. S. H.; Wortham, H.; Marchand, N. Evolution of the chemical fingerprint of biomass burning organic aerosol during aging. Atmos. Chem. Phys. 2018, 2018, 7607-7624.

(47) Pettersson, E.; Boman, C.; Westerholm, R.; Boström, D.; Nordin, A. Stove Performance and Emission Characteristics in Residential Wood Log and Pellet Combustion, Part 2: Wood Stove. Energy Fuels 2011, 25 (1), 315-323.

(48) Boman, C.; Pettersson, E.; Westerholm, R.; Boström, D.; Nordin, A. Stove Performance and Emission Characteristics in Residential Wood Log and Pellet Combustion, Part 1: Pellet Stoves. Energv Fuels 2011, 25 (1), 307-314.

(49) Aurell, J.; Gullett, B. K.; Tabor, D.; Touati, A.; Oudejans, L. Semivolatile and Volatile Organic Compound Emissions from WoodFired Hydronic Heaters. Environ. Sci. Technol. 2012, 46 (14), 78987904.

(50) Tiitta, P.; Leskinen, A.; Hao, L.; Yli-Pirilä, P.; Kortelainen, M.; Grigonyte, J.; Tissari, J.; Lamberg, H.; Hartikainen, A.; Kuuspalo, K.; Kortelainen, A. M.; Virtanen, A.; Lehtinen, K. E. J.; Komppula, M.; Pieber, S.; Prévôt, A. S. H.; Onasch, T. B.; Worsnop, D. R.; Czech, H.; Zimmermann, R.; Jokiniemi, J.; Sippula, O. Transformation of logwood combustion emissions in a smog chamber: formation of secondary organic aerosol and changes in the primary organic aerosol upon daytime and nighttime aging. Atmos. Chem. Phvs. 2016, 16 (20), 13251-13269.

(51) Corbin, J. C.; Keller, A.; Lohmann, U.; Burtscher, H.; Sierau, B.; Mensah, A. A. Organic emissions from a wood stove and a pellet stove before and after simulated atmospheric aging. Aerosol Sci. Technol. 2015, 49 (11), 1037-1050.

(52) Kumar, N. K.; Corbin, J. C.; Bruns, E. A.; Massabó, D.; Slowik, J. G.; Drinovec, L.; Močnik, G.; Prati, P.; Vlachou, A.; Baltensperger, U.; Gysel, M.; El-Haddad, I.; Prévôt, A. S. H. Production of particulate brown carbon during atmospheric aging of wood-burning emissions. Atmos. Chem. Phys. Discuss. 2018, 18 (24), 17843-17861.

(53) Czech, H.; Sippula, O.; Kortelainen, M.; Tissari, J.; Radischat, C.; Passig, J.; Streibel, T.; Jokiniemi, J.; Zimmermann, R. On-line analysis of organic emissions from residential wood combustion with singlephoton ionisation time-of-flight mass spectrometry (SPI-TOFMS). Fuel 2016, 177, 334-342.

(54) Czech, H.; Miersch, T.; Orasche, J.; Abbaszade, G.; Sippula, O.; Tissari, J.; Michalke, B.; Schnelle-Kreis, J.; Streibel, T.; Jokiniemi, J.; Zimmermann, R. Chemical composition and speciation of particulate organic matter from modern residential small-scale wood combustion appliances. Sci. Total Environ. 2018, 612, 636-648.

(55) Pieber, S. M.; Kambolis, A.; Ferri, D.; Bhattu, D.; Bruns, E. A.; Elsener, M.; Kröcher, O.; Prévôt, A. S. H.; Baltensperger, U. Mitigation of Secondary Organic Aerosol Formation from Log Wood Burning 
Emissions by Catalytic Removal of Aromatic Hydrocarbons. Environ. Sci. Technol. 2018, 52 (22), 13381-13390.

(56) Czech, H.; Pieber, S. M.; Tiitta, P.; Sippula, O.; Kortelainen, M.; Lamberg, H.; Grigonyte, J.; Streibel, T.; Prévôt, A. S. H.; Jokiniemi, J.; Zimmermann, R. Time-resolved analysis of primary volatile emissions and secondary aerosol formation potential from a small-scale pellet boiler. Atmos. Environ. 2017, 158, 236-245.

(57) Elsasser, M.; Busch, C.; Orasche, J.; Schön, C.; Hartmann, H.; Schnelle-Kreis, J.; Zimmermann, R. Dynamic changes of the aerosol composition and concentration during different burning phases of wood combustion. Energy Fuels 2013, 27 (8), 4959-4968.

(58) http://ec.europa.eu/growth/industry/sustainability/ ecodesign_en. (accessed September 10, 2017).

(59) Salzmann, R.; Nussbaumer, T. Fuel staging for NOx reduction in biomass combustion: Experiments and modeling. Energy Fuels 2001, 15 (3), 575-582.

(60) de Gouw, J.; Warneke, C. Measurements of volatile organic compounds in the earth's atmosphere using proton-transfer-reaction mass spectrometry. Mass Spectrom. Rev. 2007, 26 (2), 223-257.

(61) Cappellin, L.; Karl, T.; Probst, M.; Ismailova, O.; Winkler, P. M.; Soukoulis, C.; Aprea, E.; Märk, T. D.; Gasperi, F.; Biasioli, F. On quantitative determination of volatile organic compound concentrations using proton transfer reaction time-of-flight mass spectrometry. Environ. Sci. Technol. 2012, 46 (4), 2283-2290.

(62) Schauer, J. J.; Cass, G. R. Source apportionment of wintertime gas-phase and particle-phase air pollutants using organic compounds as tracers. Environ. Sci. Technol. 2000, 34 (9), 1821-1832.

(63) Drinovec, L.; Močnik, G.; Zotter, P.; Prévôt, A. S. H.; Ruckstuhl, C.; Coz, E.; Rupakheti, M.; Sciare, J.; Müller, T.; Wiedensohler, A.; Hansen, A. D. A. The "dual-spot" Aethalometer: an improved measurement of aerosol black carbon with real-time loading compensation. Atmos. Meas. Tech. 2015, 8 (5), 1965-1979.

(64) Andreae, M. O.; Merlet, P. Emission of trace gases and aerosols from biomass burning. Global Biogeochemical Cycles 2001, 15 (4), 955966.

(65) Ward, D. E.; Radke, L. F., Emissions measurements from vegetation fires: A comparative evaluation of methods and results, In Fire in the Environment: The Ecological, Atmosphere, and Climatic Importance of Vegetation Fires; Crutzen, P. J., Goldammer, J. G., Eds.; Jolm Wiley \& Sons Ltd, 1993.

(66) Kaltschmitt, M.; Hartmann, H. (2001) Grundlagen der Festbrennstoffnutzung. Kaltschmitt, M., Hartmann, H., Eds.; Springer: Berlin, Heidelberg, pp 239-247.

(67) Gabey, A. M.; Vaitilingom, M.; Freney, E.; Boulon, J.; Sellegri, K.; Gallagher, M. W.; Crawford, I. P.; Robinson, N. H.; Stanley, W. R.; Kaye, P. H. Observations of fluorescent and biological aerosol at a highaltitude site in central France. Atmos. Chem. Phvs. 2013, 13 (15), 74157428.

(68) Robinson, N. H.; Allan, J. D.; Huffman, J. A.; Kaye, P. H.; Foot, V. E.; Gallagher, M. Cluster analysis of WIBS single-particle bioaerosol data. Atmos. Meas. Tech. 2013, 6 (2), 337-347.

(69) Crawford, I.; Ruske, S.; Topping, D. O.; Gallagher, M. W. Evaluation of hierarchical agglomerative cluster analysis methods for discrimination of primary biological aerosol. Atmos. Meas. Tech. 2015, 8 (11), 4979-4991.

(70) Nussbaumer, T. Combustion and Co-combustion of Biomass: Fundamentals, Technologies, and Primary Measures for Emission Reduction. Energy Fuels 2003, 17 (6), 1510-1521.

(71) Mitchell, E. J. S.; Lea-Langton, A. R.; Jones, J. M.; Williams, A.; Layden, P.; Johnson, R. The impact of fuel properties on the emissions from the combustion of biomass and other solid fuels in a fixed bed domestic stove. Fuel Process. Technol. 2016, 142 (SupplementC), 115123.

(72) Rogge, W. F.; Hildemann, L. M.; Mazurek, M. A.; Cass, G. R. Sources of Fine Organic Aerosol. 9. Pine, Oak, and Synthetic Log Combustion in Residential Fireplaces. Environ. Sci. Technol. 1998, 32 (1), 13-22.
(73) Simoneit, B. R. T. Biomass burning - a review of organic tracers for smoke from incomplete combustion. Appl. Geochem. 2002, 17 (3), $129-162$.

(74) Guerrero, F.; Yáñez, K.; Vidal, V.; Cereceda-Balic, F. Effects of wood moisture on emission factors for PM2.5, particle numbers and particulate-phase PAHs from Eucalyptus globulus combustion using a controlled combustion chamber for emissions. Sci. Total Environ. 2019, 648, 737-744.

(75) Chomanee, J.; Tekasakul, S.; Tekasakul, P.; Furuuchi, M.; Otani, Y. Effects of Moisture Content and Burning Period on Concentration of Smoke Particles and Particle-Bound Polycyclic Aromatic Hydrocarbons from Rubber-Wood Combustion. Aerosol Air Oual. Res. 2009, 9, 404-411.

(76) Akagi, S. K.; Yokelson, R. J.; Wiedinmyer, C.; Alvarado, M. J.; Reid, J. S.; Karl, T.; Crounse, J. D.; Wennberg, P. O. Emission factors for open and domestic biomass burning for use in atmospheric models. Atmos. Chem. Phrs. 2011, 11 (9), 4039-4072.

(77) Alexander, M. E.; Cruz, M. G. Limitations on the accuracy of model predictions of wildland fire behaviour: A state-of-the-knowledge overview. For. Chron. 2013, 89 (03), 372-383.

(78) Holzinger, R.; Warneke, C.; Hansel, A.; Jordan, A.; Lindinger, W.; Scharffe, D. H.; Schade, G.; Crutzen, P. J. Biomass burning as a source of formaldehyde, acetaldehyde, methanol, acetone, acetonitrile, and hydrogen cyanide. Geophys. Res. Lett. 1999, 26 (8), 1161-1164.

(79) Sekimoto, K.; Koss, A. R.; Gilman, J. B.; Selimovic, V.; Coggon, M. M.; Zarzana, K. J.; Yuan, B.; Lerner, B. M.; Brown, S. S.; Warneke, C.; Yokelson, R. J.; Roberts, J. M.; de Gouw, J. High- and lowtemperature pyrolysis profiles describe volatile organic compound emissions from western US wildfire fuels. Atmos. Chem. Phys. 2018, 2018, 9263-9281. 